\section{II. バーナーの性能}

バーナーはその不可欠条件として，如何によく霧化 し得るかということであり，これとは噴雺角度の広い というこそがそのエレメントの一つになる。それは然 焼空気との接触表面積が大きくなるからである。しか るでき得る限り低圧で使用し得ること, ソフトフレー ムであること，噴油量にムラなくなた容易に量的の変 化沁応じられること等は，そのバーナーの良否を決定 付ける条件である。

次に燃焼飞要する時間の点については, 燃料が多量 な程長〈延びる。ボルガノオイルバーナ一の場合は 1 時間当 $100 l$ の油を燃焼の際その燃焼完了の距離を約 $1.0 \mathrm{~m}$ としている。

ボルガノオイルバーナーでは $14 \%$ 以上の $\mathrm{CO}_{2}$ の析 出を見る。な扮重油は石炭の場合より效率が悪いと か，筀を爆発させたとか，時に耳にするがこれはとの 大部分がバーナーの粗悪飞負 5 責任であり, 他の部分 は取扱者の不注意起因するものである。

\section{III. 使用重油に関して}

A.B 及 $C$ 重油等は何れも $10,000 \mathrm{kcal} / \mathrm{kg}$ 位の発 熱量を有している。このうち特にC 重油は比重が重く したがって粘度が高く, 到底そのままの状態では燃焼 不可能で, これの粘度を下げる方法として, 加熱する のが最も妥当である。第一段階として，まずポンプで
送油できる程度 (C重油で約 $30^{\circ} \mathrm{C}$ ) 飞,次に然焼に適 応する粘度飞加熱する。この場合加熱方法として直接 加熱は避けるとと。これは油のクラッキングその他不 都合な現象を起し，燃焼不可能に陷りさせる。また油 温は $135^{\circ} \mathrm{C}$ 以上は如何なる場合にす加熱することは許 されない。な招，ここで逆説的な言い方をすれば加熱 さえ適当とすれば結構粗悪な油でも充分飞使用できる といらことである。普通 $\mathrm{C}$ 重油で $80^{\circ} \mathrm{C}, \mathrm{B}$ 重油で $70^{\circ} \mathrm{C}$ 位が適当である。

\section{IV. 寗と炬の構造}

高温による燃焼室炉壁煉瓦の焼損を保護する意味と 燃焼用空気を予熱する一石二鳥の作用を兼ねて，炉壁 の中を空気を通過せしめ，この空気が徚瓦を冷却する そ同じに自身は予熱されて，圭れが燃焼空気として導 かれるようとしている。

石炭焚飞対して, 重油の焼成時間の短縮に括いては 約との $1 / 4$ を短縮することは可能である。な物，今後 の問題として, 重油による完全燃焼ガス化という特質 を生かして，石炭焼成江和いてサ巾に入れて焼くのを そのサヤの周囲と上部等に孔を数個あけて自由にガス を接触させては如何？このことは焼成時間の短縮は ・もちろん，燃料消費の減少により製品原価の切下げに 及ぼす点は多大なるのがあると思う。

そして，乙の方法による製品の歩止りを100\% とす ることを念願としている。

\title{
重油の性状とその需 要
}

\section{吉 田 信 一 郎*}

重油の性状とその需要について簡単と述べる。需要

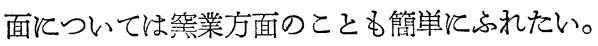

\section{I. 重油とは}

さて重油とは如何なる物かていうと, 石油原油を蒸 溜して比較的低沸点の部分を除いた釜残油を主体とし たあのである。

低滞点部分というと, 揮発油, 灯油, 軽油といった ようなもので, 釜残油は比較的滞点の高い油とアスフ ァルト質といったようなるのである。るちろん，石油 の原油の種類によっては, 揮発性の軽質分のごく少い

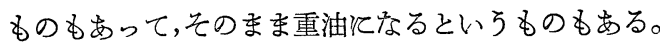
しかし，いま述べたととろの釜残油がそのまま重油に

* 大協石油株式会社研究所長 薬学博士
なるという訳ではない。わが国では，重油とはA重油 B重油，C重油というょうな規格があるから，それと 合せるために軽質油をまぜたり，いろいろ調合して所 要の性状のるのにしなければならない。

重油の用途とい党ば，ほとんぞが燃料であるが，使 用方法によって大体次の二つの種類に区分される。

(1) 焚料重油 (バンカー重油)

（2）デーゼル重油

バンカー重油はボイラーや各種燃焼炉等に燃料とし て焚燃せしめるもので, 船舶や工業的広く使用され ている。

ヂーゼル重油は漁船, 商船等のヂーゼル機関の燃料 で, 前述の $\mathrm{A}$ 重油, B重油, C 重油という規格のうち で，A重油が主としてヂーゼル機関の然料に用いられ 
ている。

バンカー重油としてはB重油，C重油が主であるが もちろんその必要性応じてA重油も用いられてい る。この A重油, B重油, C 重油の主なる違いは粘度 と残留炭素分といったようなものでせる。

本日は䌜方面の方が多いので, 主としてバンカー 重油について述べる。

燃料としての重油の需要は近来とみに増加して来 た。「化学と工業」 6 月号に炤和石油の藤沢さんもこの ことを書いているが，昭和26年の半ばより炤和28年に かけて石岸より重油への転換工場は非常な増加ぶりで 26 年 6 月から 27 年 8 月の間の転換工場数は，一般 産業 940 工場, 電力関係工場 13 工場, 計 953 工場々 いわれている。この原因は石炭に比べて重油の方がよ り理想的であるといら一語とつきる。

すなわち，然料として石炭と重油の優少性を考学る z

（1） 発熱量が約 2 倍あって, 熱効率を高度に得ら れる。

（2）灰が無く，したがって顕熱損失がなく，また 灰捨の問題がない。

（3）輸送や貯蔵が簡単であり,計量が正確である。

（4）燃焼操作が簡単であり，人件費が少ない。

（5）点火が早く, 急停止が可能であり, 過不足は ただちと調節できる。

（6）燃焼設備,建設費が安く，から維持費も安い。

（7）貯蔵や設備面積が狭くてすみ，かつ清潔で, 石炭のような自然発火というょうな始末困る ことが起きない。

といらように非常飞長所が多い。しかも值段の点はど 了かというと, 現在水蒸気 $1 \mathrm{t}$ 生産する場合, 然料費 は重油つ方が石炭より約 150 円程安くなるということ である。これは長い目で見ると大きな金額になること はいうふでもない。

以上の利点を具体的にいらと，石炭の発熱量は大体 $4,500 \sim 8,000 \mathrm{kcal} / \mathrm{kg}$ であるが，重油は大体 10,000 $\mathrm{kcal} / \mathrm{kg}$ ある。

その上熱効率が他の石炭その他の燃料比比べて割合 に良いのである。各種燃料の熱効率の比䡥は

$\begin{array}{ll}\text { 開放式石炭加熱 } & 20 \% \\ \text { ボイラー石炭加熱 } & 50 \sim 70 \% \\ \text { 電 熱 加 熱 } & 15 \sim 20 \% \\ \text { ガ ス 加 熱 } & 30 \% \\ \text { 重 油 加 熱 } & 60 \sim 80 \%\end{array}$

といわれている。

以上の諸点を考えても，石炭を重油俥換するとい うことは企業の合理化役役つといらことが了解され る。
しかし，実際に石炭を重油に切り代える場合，重油 の便利なことは解ったが，燃料原料として将来ともと 入手が順調に可能であるかどらかということが問題と なる。この疑問は誠㳊すっとすなとで，わが国机 ける石油資源は非常飞少く, 原油の生産量は戦前戦後 を通じて年間 40 万 $\mathrm{k} l$ を越觉たことがない。しかるに 現在わが国の需要量はどれ位かといらと，昨 27 年度 の歴年推定需要量は 500 万 $\mathrm{k} l$ で，この需要量と対し わが国の生産量は僅か江 $7 \%$ 位にしか過ぎない。その 他はすべて輸入に待っているといらことになる。元来 原油の埋蔵量は地理的に偏在していて, 石油を生産す る地域と石油を消費する地域との間には不同があって

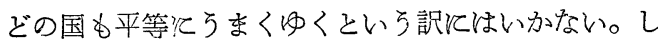
たがって，石油業というものは世界的なスケールの上 飞立ってこれを計画的㳊営して行かなければならな くなる訳である。

こういう目的に対し，アメリカ政府の石油行政担当 機関でめる国防石油局飞外国石油供給委員会という機 関があって,アメリカの国際市場飞関係のある石油会 社全部がこの委員となり，またイギリスの国際的大石 油会社もオブザーバーの形で委員を出してこれと参加 し，アメリカのフレンドリーネーション，すなわち米 英と友好的関係にある国々の石油供給を䛯節するとい うことを使命として活動している。例总ば，ある所て 急供給が娍ずるとか，あるいはまた急消費が増大 したとかいうょうな場合，それを直ちと調節する具体 案を作成してアメリカ政府飞進言するということにな っている。そして，現在では，と9国注対し供給を磪定 てていて，方が国もその中に入っている。これ沅入っ ているということは，ある程度石油つ供給が保証され ていることを意味する。このように石油業というもの は世界的スケールで経営されているという特徽がある ので，現在のところ原油の輸入について不足が生ずる ということは無いようと考劣られる。かつ，国内の製 油能力も急速济諎が充実してきた結果, 昭和 19 年 そ括ける国内製油能力が年間 412 万 $\mathrm{k} l$ であったすの が，昭和 27 年飞は 3,750 万 $\mathrm{k} l$ 飞増加して，戦前を 凌駕するにいたった。

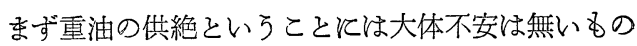
と考㝋られる。

\section{II. 重油の性状}

重油もその原料である石油原油によって種々性質が 違って来る。原油はその主成分である炭化水素の種類 そよってパラフィン系原油, ナフテン系原油, パラフ イン乱よびナフテン混合系原油分けられている。

これらの原油から造られた重油の組成もきわめて複 雑で, その化学構造といったようなととはほとんどま 
だ解っていない状態である。一般に重油を構成してい る主な要素は炭素, 水素, 酸素, 空素, 硫黄执よび少量 の鉱物性の物質からなっている。分子量は300 1, 400 程度の各種炭化水素化合物で, 平均の分析は炭素84.5 $\%$, 水素 $12.0 \%$, 酸素乙窒素 $15 \%$, これと僅かの水分 が含まれている。水分は規格では A 重油とB重油では $1 \%$ 以下，C重油では $2 \%$ 以下と定められている。硫 黄分は原油によって多少異なるが大体 $1 \%$ 位である。

さて, 重油の性状のうちで大切なるのは何かていう 々引火点, 凝固点または流動点, 水分拉よび沈澱物, 灰分, 硫黄分, 発熱量, 粘度, 安定性, 残留炭素であ る。このうち筭業方面に比較的関係の深い発熱量, 硫 黄分, 灰分等次ついて簡単飞述べる。

ガラスの製造には原料を調合して熔融する訳でする が, 大体 $1,400 \sim 1,500^{\circ} \mathrm{C}$ という高温度が要求される そ聞いている。また，セメント工業でも焼成帯つ温度 は $1,000 \sim 1,450^{\circ} \mathrm{C}$ とら高温が必要だと聞いてい る。こういう方面では発熱量ということが大切だと想 像される。重油つ発熱量は大体 $10,000 \mathrm{cal} / \mathrm{kg}$ からち ょっとそれを上まわる位であるが，もちろん上手に完 全な燃焼を行わなければ意味はない。まず空気の量で あるが，理論空気量のみでは然料の各部と空気の接触 が充分でないから，過剩の空気を必要とするのはもち ろんであるが石炭のような固体燃料と違って, 重油等 の夜体燃料では通常バーナーから哮的させて空気と良 く混合させて燃焼させるので, 過剩空気は極めて少く て良いこととなる。完全㜣焼つ立場から見ると空気の 量が多い程良いということになるが，然焼ガスが増加 すると通風を阻害し，また，燃焼温度が低下するから 熱效率が悪くなることはご承知の通りである。それで できるだけ少い空気で完全燃桄させるということが必 要であるが、それには空気と然料と良く混合接触させ ること，すなわち重油をできるだけ微粒子にまで唂霧 化させることが大切な条件沈ってくる。そして噴霧 化させるために泩粘度とか, 残留炭素とか安定性など といらことが問題となってくる。

もらろん, 粘度が適当でなケれば完全な貲霧化が行

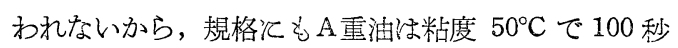
以下, B重油は 100 250 秒, $\mathrm{C}$ 重油は 1,000 秒以 下と定められている。高粘度の油では適当な温度まで 暖めて噴霧汇適当な粘度にして用いる。

残留炭素分というのは，重油を蒸㷬沉した時汇残る 炭素の量であって，含有されている鉱物性物質もこの 中に入って来る。これは必ずしも遊離炭素つ形で油の 中混っているわけではない。残炭の多い重油は一般 そアスファルト質成分の多いととを示す。また, 環状
炭化水素の高分子成分を含む重油は酸化されたり重合 したりすると, 粒子はだんだん大きくなり, 徐々と溶 液の状態からコロイドの状態へ,さらと憼濁の状態と なり, 空気触れたり熱が加兑られたりするとますま すその量が多くなって分離沈下して来るようになる。 これをスラッジと呼んでいるが，大体ゴム質，アスフ アルト質, 重合物質, 炭素質, 泥水分といったような ものから成っている。

こういう重油はタンクの底にスラッジが沜降附着す るだけで無く，パイプ等に和ける流動性も悪くなるし バーナーのノズル孔を閉塞したり, その附近にカーボ ンの析出を見たりする。普通こういう性質は, 単飞原 油をそのま蒸溜して得た釜残油を主成分にした重油 より，それらと分解蒸溜の釜残油を混合して作った重 油の方にこういう性質が多いようにいわれている。

そこで, かがスラッジの析出を防止するためと添 加剤を用いることがある。これらの添加剤は輸入品も あり, 国産のものもあり, 燃料助猎とか助燃猎とかい う名で種々発売されているが，大体との性能は燃焼触 媒型と界面活性剤型飞大別される。しかし, 大部分の 製品は後者の界面活性㓣型で，スラッジ分を微細に油 中に懸在せしめ, 乳化のような状態にしてスラッジ分 の沈降附着を防止し, 容器や配管を清浄江保って流動 性を良くし，ノズルの閉塞等を防止すると共飞嘪霧を 微細炕して燃焼を助けるといったようなことを主眼に している。

重油の斥分は誠少量でめって, 通常0.5 1.5\%位 である。灰分飞出て来る元素は珄素, 鉄, アルミニウ ム, ナトリウム, 硫黄, カルシウム, マグネシウム, マンガン, ニッケル等で, 原油によってはヴァナジウ ムなども含んでいる。このうちで比較的量の多いのは 珪素飞鉄であるから，白色ポルトランドセメント等鉄 分をきらう場合には戊分の少い重油を選択する要があ る。

硫黄分は重油が燃焼する際飞亜硫酸ガスとなって煙 道から排出されるから, 通常は特にこのため府蝕等で 困るということはないが，重油の燃焼がうまくない場 合に生じたカーボンに亜硫酸ガスが吸着され，そのカ 一ボンが金属面に附着してそと腐蝕が起るというよ うなととをいっている人すあるから，その意味でも然 焼は完全に行うことが望ましい。

な怙，ガラス工業やデリケートな墨業方面で硫黄分 が製品の着色等に影響がある場合，なるべく硫黄分の 少い重油を選択せね翏ならない。かかる場合には燃料 として重油のみにこだわらず，さらと硫黄分の少い軽

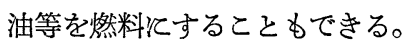

